\title{
Erratum bij: Krachtige basiszorg
}

\section{Meer tijd én anders werken en organiseren}

\section{Jacqueline van Riet · Nikki Makkes · Petra van Wezel · Marc Roosenboom}

\section{Erratum bij:}

Bijblijven 3/4 - 2018

Gezondheidsverschillen en persoonsgerichte integrale eerstelijnszorg. https://doi.org/10.1007/s12414-018-0312-8

In het artikel 'Krachtige basiszorg. Meer tijd én anders werken en organiseren' (pag. 289) door Jacqueline van Riet, Nikki Makkes, Petra van Wezel en Marc Roosenboom is een fout figuurbijschrift opgenomen. Het bijschrift bij fig. 1 moet zijn:

Figuur 1 4D-Model Professional Subitems @ Jacqueline van Riet en Nikki Makkes, Stichting Overvecht Gezond

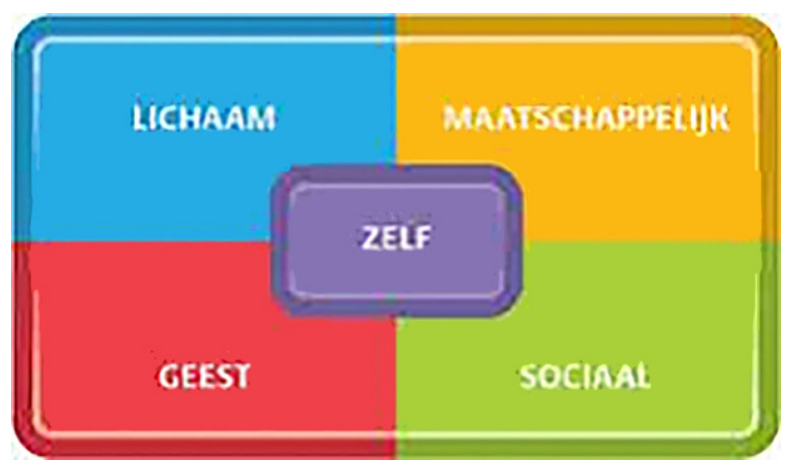

De oorspronkelijke-bijdrage vindt u op https://doi.org/10.1007/s12414-018-0312-8.

J. van Riet $(\varangle) \cdot$ N. Makkes $\cdot$ P. van Wezel

Utrecht, Nederland

e-mail: j.vanriet@overvechtgezond.nl

M. Roosenboom

Gezonde Focus, Werkhoven, Nederland

Bijblijven (2018) 34:857, https://doi.org/10.1007/s12414-018-0359-6

(C) Bohn Stafleu van Loghum is een imprint van Springer Media B.V., onderdeel van Springer Nature 2018

Published online: 9 November 2018 